\title{
Photocatalytic and biological oxidation treatment of real textile wastewater
}

\author{
Teklit Gebregiorgis Ambaye ${ }^{1,2} \cdot$ Kiros Hagos $^{3}$
}

Received: 17 September 2020 / Accepted: 3 November 2020 / Published online: 19 November 2020

(c) The Author(s) 2020

\begin{abstract}
In this study, the discoloration of wastewater containing azo dyes by chemical oxidation process combined with a biological treatment was evaluated and applied to real textile wastewater generated from one Ethiopian industrial site. The use of $\mathrm{TiO}_{2}$ as photocatalyst and the effect of the addition of $\mathrm{H}_{2} \mathrm{O}_{2}$ on color removal was first investigated. Photocatalysis was followed by aerobic biological treatment, and their combination resulted in a high extent of color removal (93.3\%) and chemical oxygen demand (COD) reduction (90.4\%). This was reached without $\mathrm{pH}$ correction and with low energy consumption compared to the implementation of AOPs alone. This study performed with real textile wastewater allows the direct extrapolation of the data for the design of a cost-effective and applicable treatment procedure at a pilot scale.
\end{abstract}

\section{Graphic abstract}
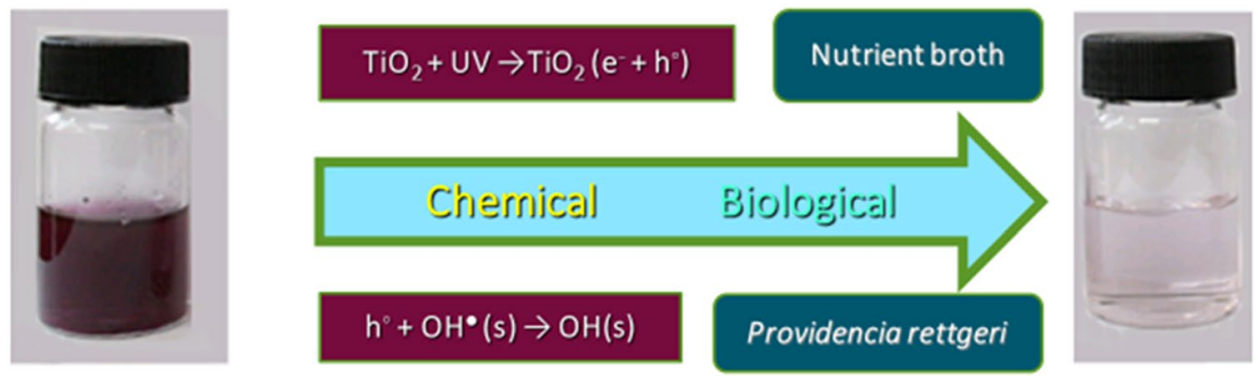

Real textile wastewater

Treated water

Keywords Decolorization · Photocatalytic degradation · Wastewater treatment · Textile industry · Titanium dioxide · Hydrogen peroxide

Teklit Gebregiorgis Ambaye

teklitgeb@gmail.com

1 Department of Civil, Environmental, Architectural Engineering and Mathematics, University of Brescia, Via Branze 43, 25123 Brescia, Italy

2 Department of Chemistry, Mekelle University, 231 Mekelle, Ethiopia

3 Mekelle Institute of Technology (MIT), Mekelle University, 1632 Mekelle, Ethiopia

\section{Introduction}

Color is the most significant contaminant resulting from textile manufacturing whereby the presence of very small amounts of dyes in water (less than $1 \mathrm{ppm}$ for some dyes) affect water transparency, gas solubility in lakes, rivers, and other water bodies [59] When compared to soluble colorless organic substances, color causes a significant additional effect on the environment and it must be removed before discharging wastewater into natural water bodies.

A large number of international and local investors are participating in the development of Ethiopian textile 
industries as they are attracted by the several investment incentive packages available in the country. This in effect has increased the amount of wastewater discharge points with repercussive implications to the environment. For instance, according to the official dispatches of the Ethiopian Textile Industry Development Institute, the sector has consumed about 48,750,967 kg of dyes and chemicals of varied types in the year 2017. Given this as one elemental factor and the alarming nature of issues related to environmental problems in the country, the government has established Environmental Protection Authority (EPA) as a regulatory and monitoring body under proclamation number 295/2002. Along with this imperative initiative, the government has proclaimed a law designed for environmental pollution control in its proclamation 300/2002. In light of these proclamations and resultant standards set out by the EPA, the treatment of wastewater remains an utmost demand. Hence, understanding, designing, and developing effective industrial wastewater treatment technology, which is environmentally convenient and economically feasible, is required.

Textile industries generate wastewaters that consist of non-biodegradable and toxic wastes streamed from different operations. Some dyestuffs are "highly structured polymers and are very difficult to decompose" [11, 29, 30]. Therefore, the efficient removal of dyes from industrial runoffs remains a major environmental concern. Different physiochemical and biological treatment methods are believed to be efficient ways for the decolorization process. Yet, these methods have not been applied for treating dye wastewater in the textile industries due to cost and disposal issues [25, 42].

Each of the physical, chemical, and biological treatment methods has their own merits and demerits. Among the different chemical methods, advanced oxidation processes (AOPs) are of ample interest in today's textile industry for the effective oxidation of a wide variety of organics and dyes stuffs [3, 8, 15, 38, 43]. Among these methods, top priority goes to semiconductor-assisted photocatalytic degradation studies; which use $\mathrm{TiO}_{2}$ or $\mathrm{ZnO}$ as a photocatalyst $[9,27]$.

According to Neppolian et al. [44], three commercial textile dyes, namely RY17, RR2, and RB4 using solar/UV radiation, were effectively removed by using titanium as a photocatalyst. It was reported by Subramani et al. (2007) that the Indigo carmine dye was photocatalyzed by $\mathrm{TiO}_{2}$ impregnated with activated carbon. $\mathrm{TiO}_{2}$-assisted photocatalytic degradation of azo dyes in an aqueous solution was reviewed by several authors (Grabowska 2016; [33, 62]). The kinetic and mechanistic pathways were also reviewed based on the intermediates identified. The photodegradation of $\mathrm{ZnO}$ was found to be similar to that of $\mathrm{TiO}_{2}$ for azo dye acid red 14; and it is gaining acceptance $[13,60]$. $\mathrm{ZnO}$ was immobilized on the surface of the glass and the photocatalysis degradation of Cibacron red was studied by [53].
The use of photocatalysis as a pre-treatment process may be a promising option to overcome limitations with bioremediation. This approach involves the enhancement of the biodegradability of dyes with the use of photocatalysis, followed by a biological process for the complete degradation of dyes by-products $[12,22]$. This treatment sequence has the advantage to be efficient and cost-effective [32, 41]. Dyecontaining effluents were successfully decolorized through the sequential use of chemical Oxidation Processes $\left[\mathrm{TiO}_{2}\right.$, $\mathrm{ZnO}$ ] followed by the biological process (aerobic bacterial consortia) [39], indicating the successfulness of this technique. On the other hand, the use of AOP as post-treatment was reported to be effective for Cibacron red and can act as an alternative to the chemical-biological strategy [23]. This combined approach indicates the possibility of subsequent biological treatment for the complete removal of organic matter at a low cost [19]. Extensive reviews and published research works argued that post-treatment of a toxic and/or non-biodegradable effluent for a short time using AOP, with optimum chemical and energy consumption, and generating an intermediate sample that can be fully and readily biodegradable is possible [45, 54]. This opens the opportunity for the complete removal of organic matter at a low cost.

Recently, efforts have been made on combining chemical reduction and biological oxidation processes for the treatment of synthetic dye of Reactive Black 5 (RB5) [20, 25, 34, 57]. This technique has been identified as a feasible technique, which effectively decreased the color, chemical oxygen demand (COD), biological oxygen demand (BOD), total suspended solid (TSS), total dissolved substance (TDS), and $\mathrm{pH}$. The ultimate aim of this combined treatment sequence is the conversion of the non-biodegradable dyes into biodegradable compounds. It was reported that sequential use of an advanced oxidation process (i.e., Fenton's reagent) followed by an aerobic biological process was effective for the removal of synthetic dyes Acid Blue 113, Acid Black 24, and Mordant Black 17 [26, 28, 37, 50]. In another study, da Silva et al. [14] reported that the combination of photocatalysis using $\mathrm{TiO}_{2}$ and anaerobic biological treatment has significantly improved the biodegradability and allowed complete removal of the color and COD. However, these authors argued that the achievement of this combined approach cannot be a guarantee and depends on the dose, type of the photocatalyst and the basic characteristics of the wastewater especially for real textile wastewater as its degradation may be entirely different due to the combination of various dyes, chemicals, suspended particles, nutrients and microbial population involved in the biological treatment. However, there is no report using $\mathrm{TiO}_{2} / \mathrm{H}_{2} \mathrm{O}_{2} / \mathrm{UV}$ combined with biological treatment and the optimization of culture conditions dealing with the treatment of real wastewater from the textile industry for color removal. 
Hence, the main objective of this study was to apply a combined chemical and aerobic biological treatment on actual wastewater generated from an Ethiopian textile plant. COD, BOD, TSS, TDS, color, and $\mathrm{pH}$ analyses were carried out on actual textile wastewater before and after chemical and biological oxidation treatments.

\section{Materials and methods}

\section{Sampling, chemicals, and analytical methods}

The real textile wastewater treated was collected from a textile plant located in Ethiopia. The type of dyes used by this plant is Azo dye (Reactive Black 5). Degradation of this azo dye was monitored spectrophotometrically by reading at $597 \mathrm{~nm}$ [59]. The decolorization rate was calculated from the difference between the initial and the final absorption values of the supernatant (Ramya et al. 2007). The physicochemical characteristics of the real textile wastewater were measured using the standard analytical procedures [1].

\section{Photocatalytic reactor, light source, and analytical methods}

For the present study, we used a batch cylindrical reactor of $200 \mathrm{~mL}$ made up of borosilicate glass having dimensions $8 \mathrm{~cm} \times 4.5 \mathrm{~cm}$ (height $\times$ diameter) with ports at the top for sampling, gas inlet, and gas outlet was used in this study. Before turning on the lamp, titanium oxide was kept in dark conditions to reach an equilibrium. The UV energy lamp selected for this study was $5.0 \mathrm{~cm}$ long with a UV output of $11 \mathrm{~W}$ used as the energy source for catalyst excitation and placed centrally, parallel to the length of the cylinder in the reactor. Experiments were performed at $25^{\circ} \mathrm{C}$ temperature. The reactor assembly was placed on a magnetic stirring plate to further enhance the agitation. For degradation experiments, $5 \mathrm{~g}$ of analytical grade titanium dioxide powder $\left(\mathrm{TiO}_{2}\right.$ Degussa P-25 (anatase 75\%, rutile 25\%, BET specific surface area of $48 \mathrm{~m}^{2} / \mathrm{g}$, and mean particle size of $25 \mathrm{~nm}$ ) and $2.6 \mathrm{~mL}$ of $30 \%$ aqueous solution of hydrogen peroxide $\left(\mathrm{H}_{2} \mathrm{O}_{2}\right.$ having $70 \%$ Water, Specific density @ $20{ }^{\circ} \mathrm{C}=1.13$ and $\mathrm{pH}$ 2.0-3.0 purchased from Neway chemicals PLC, Ethiopia) were added to the $25 \mathrm{~mL}$ of real textile wastewater. The suspension was subjected to irradiation under UV $11 \mathrm{~W}$ for a fixed interval of time. At 5-h time intervals, aliquots were taken out with the help of a syringe and then filtered through a Millipore syringe filter of $0.45 \mu \mathrm{m}$. This sample was subjected to spectrophotometric analysis to monitor the dye photodegradation at the $\lambda_{\max }(597 \mathrm{~nm})$ (Kansal et al. 2005).

\section{Degradation studies of selected azo dyes with biological method}

The bacterial culture that was used in this experiment was isolated from textile effluent contaminated soil and selected based on its capacity to degrade textile azo dye; it was a Providencia rettgeri strain HSL1 (Genebank accession no. JX853768.1). The stock culture of the bacterial strain was maintained at $4.0 \pm 0.2{ }^{\circ} \mathrm{C}$ on a nutrient medium slant containing $1 \%$ textile effluent to retain their dye decolorizing abilities.

A Providencia rettgeri HSL1 bacterial culture was enriched in 250-mL Erlenmeyer flask containing $100 \mathrm{~mL}$ of nutrient broth having a composition $(\mathrm{g} / \mathrm{l})$ of sodium chloride 5.0, and 1.5, yeast extract $(10 \%(\mathrm{v} / \mathrm{v}))$ of nutrient broth aliquots for $24 \mathrm{~h}$ under microaerophilic conditions. The enriched inoculum was then used for further degradation of the biodegradable COD.

\section{Combined chemical and biological treatment}

Photocatalytic degradation of the selected azo dyes was carried out in a photobioreactor in the presence of a catalyst under the conditions optimized earlier for the specified period. This step was followed by the addition of the microbial inoculum. Degradation studies were carried out at 5-h time intervals, and samples were withdrawn, centrifuged, and filtered through a $0.45-\mu \mathrm{m}$ membrane filter. COD, BOD, TSS, TDS, color, and $\mathrm{pH}$ analyses of the permeate were carried out for both photocatalytic and biological steps of the process according to standard operating procedures [1].

\section{Statistical data analysis}

The statistical difference of the COD, BOD, TSS, TDS, color, and $\mathrm{pH}$ analyses for the real textile wastewater before and after the chemical-biological oxidation reaction was determined using Origin-Lab (version 8.0773).

\section{Result and discussion}

\section{Textile wastewater characteristics}

From the data reported in Table 1, the chemistry of the wastewater and the potential treatment options may be revealed. The biological oxygen demand BOD/COD ratio of 0.2 suggests that the treatment of this wastewater through biological methods is not favorable due to low effluent biodegradability [55] . Moreover, some other 
Table 1 Real textile wastewater characteristics

\begin{tabular}{lc}
\hline Parameters & Average value \pm SD \\
\hline $\mathrm{pH}$ & $8.1 \pm 0.1$ \\
$\mathrm{COD}(\mathrm{mg} / \mathrm{L})$ & $1250.5 \pm 0.1$ \\
$\mathrm{BOD}(\mathrm{mg} / \mathrm{L})$ & $250.5 \pm 0.1$ \\
$\mathrm{TSS}(\mathrm{mg} / \mathrm{L})$ & $1150.5 \pm 0.2$ \\
$\mathrm{TDS}(\mathrm{mg} / \mathrm{L})$ & $3000.2 \pm 0.1$ \\
Color $(\mathrm{PCU})$ & $75.0 \pm 0.1$ \\
\hline
\end{tabular}

parameters, TSS, $\mathrm{pH}$, and color, were also in favor of the use of a combined method instead of single biological methods.

\section{Photodegradation of textile wastewater under UV irradiation using $\mathrm{TiO}_{2}-\mathrm{H}_{2} \mathrm{O}_{2}$}

Advanced oxidation processes (AOPs) produce a highly reactive non-specific oxidant called hydroxyl radicals $(\mathrm{OH} \bullet)$, capable of destroying a wide range of organic pollutants in water and wastewater [57]; presently, destruction of real textile wastewater having $\mathrm{RB} 5$ using $\mathrm{TiO}_{2} / \mathrm{H}_{2} \mathrm{O}_{2} / \mathrm{UV}$ photocatalytic process is one of the various advanced oxidation processes applied.

Increasing the $\mathrm{TiO}_{2}-\mathrm{H}_{2} \mathrm{O}_{2}$ dose improved COD and BOD degradations, TSS removal, and decolorization. During $5 \mathrm{~h}$ of treatment with $1 \mathrm{~g} \mathrm{TiO}_{2}-0.5 \mathrm{~mL} \mathrm{H}_{2} \mathrm{O}_{2}$ dose, the photocatalytic removal efficiency was $10.42 \%, 10.05 \%, 4.35 \%$, and $15.4 \%$ for from textile wastewater COD, BOD, TSS, and color, respectively (Table 2); and the treatment efficiency increased with the time and the amounts of $\mathrm{TiO}_{2}$ and $\mathrm{H}_{2} \mathrm{O}_{2}$ until removal yields of $36.0 \%, 39.23 \%, 26.90 \%$, and $44.73 \%$ for COD, BOD, TSS, and color after $25 \mathrm{~h}$ of treatment using $5 \mathrm{~g}$ of $\mathrm{TiO}_{2}$ and $2.5 \mathrm{~mL}$ of $\mathrm{H}_{2} \mathrm{O}_{2}$, respectively. These results are in agreement with a previous report [7, 51], showing that photodegradation of textile wastewater increases with increasing the concentrations of an oxidant by applying $\mathrm{TiO}_{2}-\mathrm{H}_{2} \mathrm{O}_{2}$ for rapid photodegradation as shown in Table 2. Besides, increasing $\mathrm{TiO}_{2}-\mathrm{H}_{2} \mathrm{O}_{2}$ dose above $5 \mathrm{~g}$ and $2.5 \mathrm{~mL}$ did not increase the color removal efficiency much. This confirms the interdependence of color and COD in the wastewater. Throughout the study, it was observed that Degussa P-25 $\mathrm{TiO}_{2}$ effectively brought out the degradation of RB5. The addition of an optimum amount of $\mathrm{H}_{2} \mathrm{O}_{2}$ to the heterogeneous photocatalytic treatment was found to enhance the degradation of real textile effluents to a large extent by accepting a photogenerated electron from a conduction band and thus promotes the charge separation and it also forms $\mathrm{OH}$ radicals. However, the photocatalytic treatment is only the first step of the proposed combined process, to improve the biodegradability of the solution to be treated to allow a subsequent biological treatment step. Generally, by increasing photocatalysts the removal efficiency and decolorization of the real textile wastewater are also increasing as shown in Fig. 1 and Table 2.

Table 3 summarizes the results of electrocoagulation, electrochemical Fenton, electro-Fenton, ozonation, photolysis, photocatalysis, photoelectrocatalysis methods, and peroxi-coagulation. The decolorization yields of real textile wastewater range from 55 to $90 \%$ [10, 18, 52]. The decolorization efficiency was found to be strongly influenced by the initial $\mathrm{pH}$ and high energy consumption with a power of $2000 \mathrm{~W}$ and recommended $\mathrm{pH}$ correction in the initial step before applied to the different chemical treatments. In contrast in this study $73 \%$, decolorization efficiency was gained without $\mathrm{pH}$ correction and less energy.

\section{Biological treatment of the pre-treated textile wastewater}

After photodegradation experiments were completed at $25 \mathrm{~h}$, biological experiments were done on the pre-treated solution, with the following initial concentrations: COD (550.12 mg/L), BOD (143.12 mg/L), TSS (720.2 mg/L), and color (20.2 PCU). The media (nutrient broth + yeast extract) was added with different respective doses $(0+0$, $1+2,2+5,3+7.5,4+9,5+1.5)$ at $30,35,40,45,50,55 \mathrm{~h}$ and the corresponding results are shown in Table 4 . Increasing the bacteria-yeast extract does improve COD and BOD degradations, TSS removal, and decolorization until removal yields of $78.12 \%, 50.87 \%, 84.04 \%$, and $75.15 \%$ for COD, BOD, TSS, and color in the presence of $5 \mathrm{~g}$ nutrient broth and $10 \%$ yeast extract during $55 \mathrm{~h}$, respectively (Table 4).
Table 2 Evolution of wastewater chemical characteristic as a function of AOP reagents added and reaction time

\begin{tabular}{llrrrr}
\hline Time $(\mathrm{h})$ & $\begin{array}{l}\mathrm{AOP} \text { TiO2 } \\
(\mathrm{g})+\mathrm{H} 2 \mathrm{O} 2(\mathrm{~mL})\end{array}$ & $\mathrm{COD}(\mathrm{mg} / \mathrm{L})$ & BOD $(\mathrm{mg} / \mathrm{L})$ & TSS $(\mathrm{mg} / \mathrm{L})$ & Color (PCU) \\
\hline 0 & $0+0$ & $1250.5 \pm 0.1$ & $250.5 \pm 0.1$ & $1150.5 \pm 0.2$ & $75.0 \pm 0.1$ \\
5 & $1+0.5$ & $1120.1 \pm 0.1$ & $225.1 \pm 0.1$ & $1100.4 \pm 0.3$ & $63.5 \pm 0.1$ \\
10 & $2+1$ & $1014.2 \pm 0.1$ & $175.1 \pm 0.1$ & $952 \pm 0.3$ & $52.2 \pm 0.1$ \\
15 & $3+1.5$ & $800.4 \pm 0.1$ & $152.2 \pm 0.1$ & $841 \pm 0.3$ & $41.5 \pm 0.1$ \\
20 & $4+2$ & $785.1 \pm 0.1$ & $148.2 \pm 0.1$ & $765 \pm 0.3$ & $33.6 \pm 0.1$ \\
25 & $5 \mathrm{~g}+2.5 \mathrm{~mL}$ & $550.1 \pm 0.1$ & $143.1 \pm 0.1$ & $720.2 \pm 0.1$ & $30.1 \pm 0.1$ \\
\hline
\end{tabular}


Fig. 1 Degradation using titanium oxide and hydrogen peroxide. The amount of titanium oxide and hydrogen peroxide added is reported in Table 2

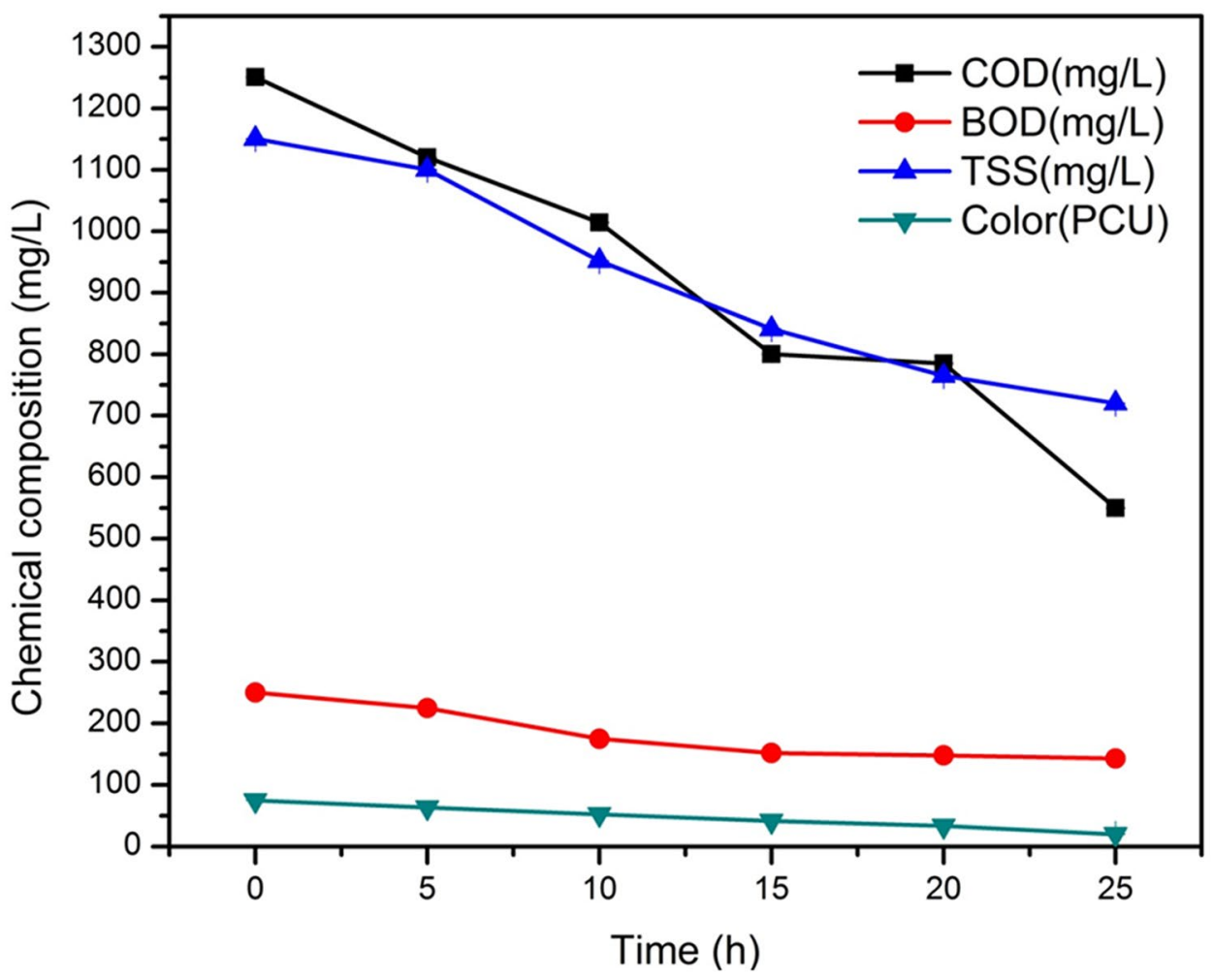

\begin{tabular}{|c|c|c|c|}
\hline Chemical treatment methods & $\begin{array}{l}\text { COD } \\
\text { removal } \\
(\%)\end{array}$ & Color removal $(\%)$ & References \\
\hline Electrocoagulation & - & 70 & Ghanbari and Moradi [24] \\
\hline Fenton method for livestock wastewater & 88 & 95.4 & Lee and Shoda [35] \\
\hline Electrochemical Fenton processes & 70.6 & 72.9 & Eslami et al. [18] \\
\hline $\begin{array}{l}\text { Combination ozonation, photolysis, photo- } \\
\text { catalysis and photoelectrocatalysis }\end{array}$ & - & 90 & Cardoso et al. [10] \\
\hline Electrocoagulation in a packed bed reactor & 96.88 & Almost all & Un and Aytac [56] \\
\hline Photodegradation using nanocatalysts & & 57.63 & Bansal and Sud [6] \\
\hline Photocatalysis & 55 & 74 & Solcova et al. [52] \\
\hline Photocatalytic benzidine-based azo dyes & 63 & 56 & Bandala et al. [5] \\
\hline $\begin{array}{l}\text { Titanium dioxide-coated glass, ceramic tile, } \\
\text { and stainless steel sheets }\end{array}$ & & 87.7 & Sirirerkratana et al. [49] \\
\hline Magnetic photocatalysts from $\mathrm{TiO}_{2}$ & & 83 & Pereira et al. [46] \\
\hline Photodegradation of azo dyes & 56 & 73.17 & Present study \\
\hline
\end{tabular}

Table 3 Literature overview of different chemical processes for the treatment of textile wastewater
Also, this yeast extract is usually used as growth stimulants or growth factors for bacteria (Li et al. [36]). The effects of yeast extract and nutrients added simultaneously on the degradation of RB5 as post-treatment by a mixed culture were first investigated in this study.

Based on the above results, it is shown that $5 \mathrm{~g}$ nutrient broth and $10 \%$ yeast extract during $55 \mathrm{~h}$ do not impact as positively on the degradation of RB5. It is reasonably believed that addition times and concentrations of yeast extract could affect cell growth on the degradation of RB5.
So, it is necessary to investigate the timing and the amount of yeast extract added to the degradation of organic pollutants. These results are in agreement with a previous report published by [47], showing that the biodegradation of textile wastewater increases with increasing the dose nutrient brothyeast for rapid biodegradation as shown in Table 4. Generally, biodegradation removal efficiency and decolorization of real textile wastewater are also increasing as shown in Fig. 2. However, the results indicated that a single biological method is not suitable for textile dye degradation [16]. 
Table 4 Time course of the wastewater biodegradation using Providencia rettgeri HSL1 growing in a culture medium containing NaCl and yeast extract

\begin{tabular}{|c|c|c|c|c|c|}
\hline Time (h) & $\begin{array}{l}\text { Bacterial cultures of Providencia rettgeri } \mathrm{HSL} 1+\text { nutri- } \\
\text { ent broth sodium chloride }(\mathrm{g})+\text { yeast extract }(\mathrm{mL})\end{array}$ & $\mathrm{COD}(\mathrm{mg} / \mathrm{L})$ & $\mathrm{BOD}(\mathrm{mg} / \mathrm{L})$ & TSS (mg/L) & Color (PCU) \\
\hline 30 & 0 nutrient $+0 \%$ yeast extract & $550.1 \pm 0.1$ & $143.1 \pm 0.1$ & $720.2 \pm 0.1$ & $30.1 \pm 0.1$ \\
\hline 35 & $1+2$ & $412.4 \pm 0.1$ & $120.1 \pm 0.1$ & $612.5 \pm 0.2$ & $25.1 \pm 0.1$ \\
\hline 40 & $2+5$ & $332.1 \pm 0.1$ & $100.2 \pm 0.1$ & $502.3 \pm 0.2$ & $15.0 \pm 0.1$ \\
\hline 45 & $3+7.5$ & $210.1 \pm 0.1$ & $85.2 \pm 0.1$ & $345.2 \pm 0.3$ & $12.0 \pm 0.1$ \\
\hline 50 & $4+9$ & $175.1 \pm 0.1$ & $75.1 \pm 0.1$ & $210.5 \pm 0.2$ & $7.1 \pm 0.1$ \\
\hline 55 & $5+10$ & $120.4 \pm 0.1$ & $70.3 \pm 0.1$ & $115.0 \pm 0.1$ & $5.0 \pm 0.1$ \\
\hline
\end{tabular}

Fig. 2 Degradation using biological method. The amount of Bacterial cultures of Providencia rettgeri HSL1 +nutrient broth sodium chloride $(\mathrm{g})+$ yeast extract $(10 \%(\mathrm{v} / \mathrm{v}))$ $(\mathrm{mL})$ added are reported in Table 3

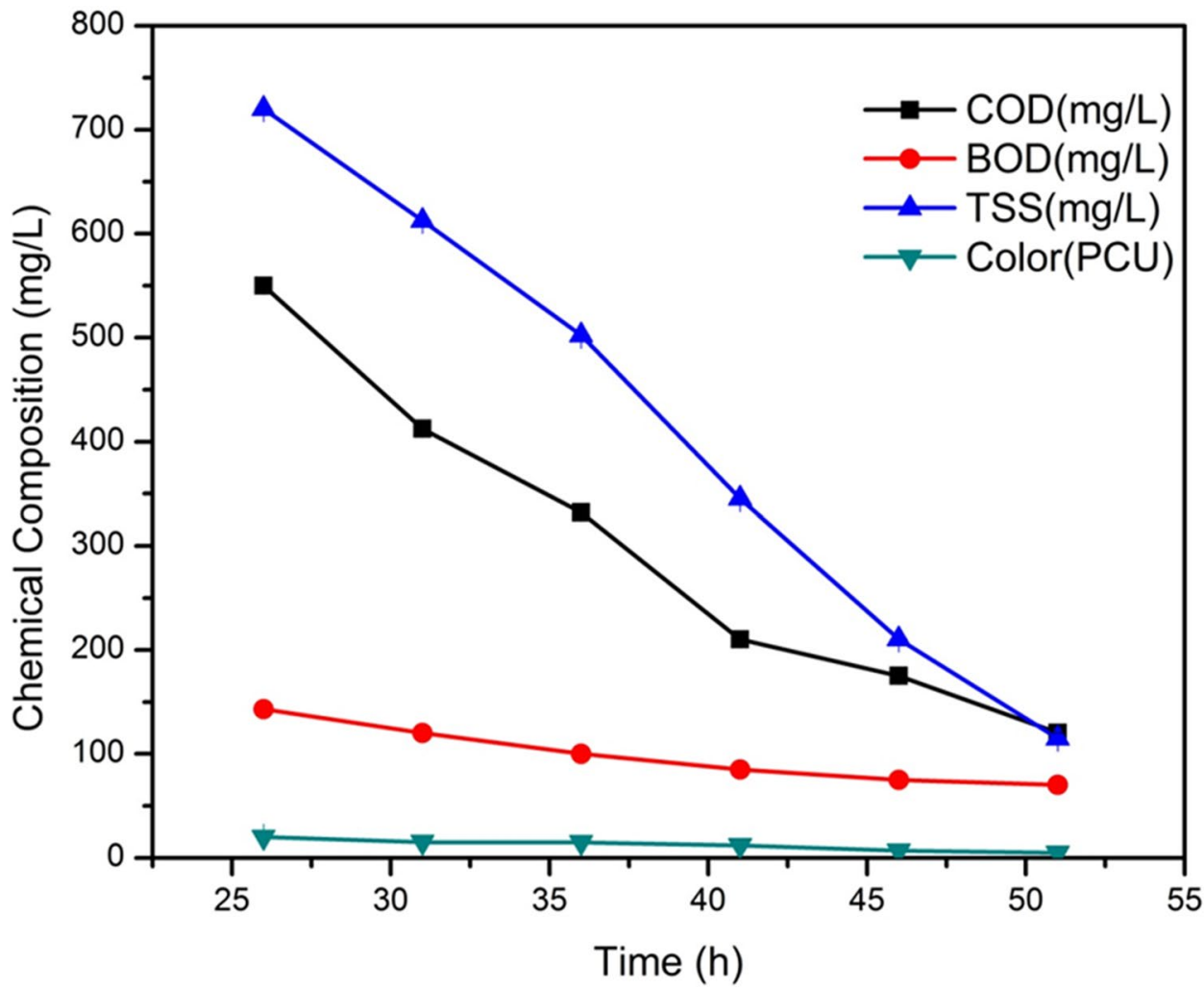

Table 5 Literature overview of different biological processes for the treatment of textile wastewater

\begin{tabular}{|c|c|c|c|c|}
\hline Biological methods & $\begin{array}{l}\text { BOD removal } \\
(\%)\end{array}$ & COD removal $(\%)$ & Color removal $(\%)$ & References \\
\hline Sequential anaerobic-aerobic process & & 75 & $70-80$ & Tomei et al. [55] \\
\hline Anaerobic degradation & & 80 & & Balamurugan et al. [4] \\
\hline Anaerobic-oxic system & & 83 & 90 & An et al. [2] \\
\hline Anaerobic process & & & 90 & Yuzer et al. [61] \\
\hline Aerobic process & & & $40-50$ & El Defrawy and Shaalan [17] \\
\hline Engineered wetland systems (EWSs) & & $53-59$ & $72-77$ & Mbuligwe [40] \\
\hline Bactria + yeast & 50.87 & 78.12 & 75.15 & Present study \\
\hline
\end{tabular}


Table 5 summarizes the results of the sequential anaerobic-aerobic process, anaerobic degradation for the decolorization of real textile wastewater. The reported decolorization yields range from 70 to $90 \%$ [2, 4, 55, 61]. Generally, the decolorization efficiency depends on the optimal fungal or bacterial strain as well as the addition of an easily degradable carbon source and also indicated that a single biological method is not suitable for a complete textile dye degradation even if the anaerobic processes were reported to be more successful. However, in the present study $75 \%$, decolorization efficiency was gained in a single aerobic process.

\section{Sequential chemical and biological treatment of textile wastewater}

To improve the pollutants removal efficiencies from the textile wastewater, the combination of photocatalytic and biological processes was examined. Given the low rate of BOD/ COD (0.2) of the sampled textile wastewater, the application of the pre-treatment method before the biological one is imperative. The real textile waste was collected before entering the chemical treatment step and was used as received, without dilution. The textile wastewater was measured with the initial values COD $1250.5 \mathrm{mg} / \mathrm{L}$, BOD $250.5 \mathrm{mg} / \mathrm{L}$, TSS $1150.5 \mathrm{mg} / \mathrm{L}$, and color $75 \mathrm{PCU}$ while its initial $\mathrm{pH}$ value was 8.1. After sequential chemical-biological treatment, the final COD, BOD, TSS, and color were reduced into respective values $120.37 \mathrm{mg} / \mathrm{L}, 70.32 \mathrm{mg} / \mathrm{L}, 114.97 \mathrm{mg} / \mathrm{L}$, and 5 PCU which are below the National Environmental Quality Standards (NEQS) of Textile Effluent as presented in Fig. 3 and Table 6 [31].

The sequential chemical-biological decolorization of real textile wastewaters is presented in Fig. 3 with 93.33\% efficiency which was decreased from 75 PCU to 5 PCU for the color parameter. Color removal has an impact on COD and BOD decrease, owing to the conversion of the complex dyes into simple molecules that are less toxic and easily degraded during the biological treatment. Consequently, in this study, the concentration of COD, BOD, and TSS was reduced to final concentrations of $120 \mathrm{mg} / \mathrm{L}, 70.32 \mathrm{mg} / \mathrm{L}$, and $114.97 \mathrm{mg} / \mathrm{L}$, namely removal efficiencies of $90.4 \%$, $71.9 \%$, and $90 \%$. The results of the present study are in line with the work of [58] and other researchers as shown in Table 7.

In summary, the decolorization of the real textile industry wastewater using AOP-biological treatment decreases the COD effluent by $90.4 \%$. The result indicated that treated wastewater firstly using AOP tends to increase mineralization of Azo Dye for COD removal, and generate biodegradable COD. This result is in agreement with Devassy et al. (2009) who stated that AOP is a powerful treatment for toxic pollutants such as the azo dyes in textile wastewater. The

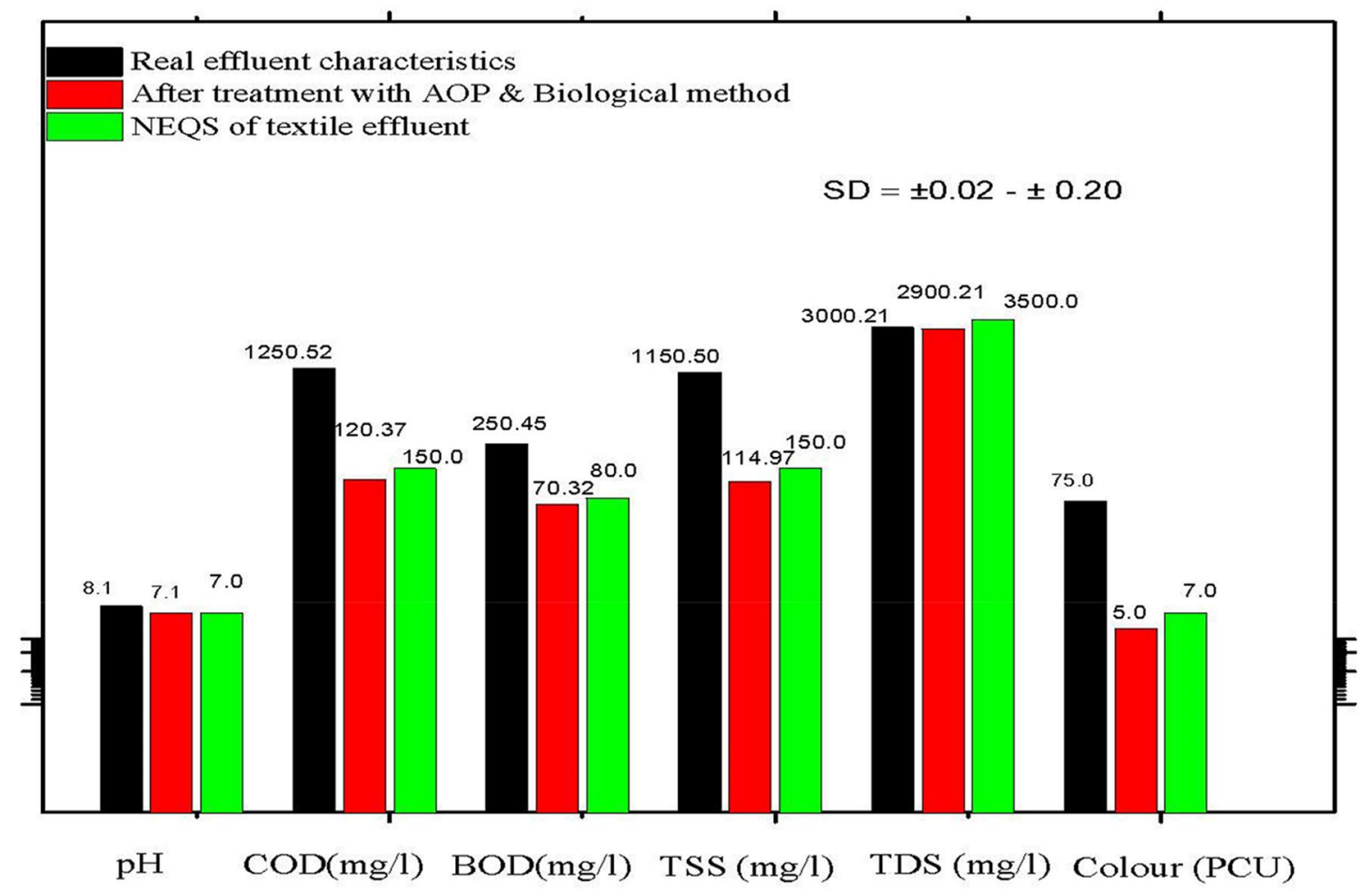

Fig. 3 Decolorization using chemical and biological method its comparison with National Environmental Quality Standards (NEQS) of Textile Effluent 
Table 6 National Environmental Quality Standards (NEQS) of Textile Effluent

\begin{tabular}{lccc}
\hline Parameters & $\begin{array}{l}\text { Real textile effluent } \\
\text { characteristics }\end{array}$ & $\begin{array}{l}\text { After treated with AOP \& } \\
\text { Biological treatment }\end{array}$ & $\begin{array}{l}\text { National Environmental Qual- } \\
\text { ity Standards (NEQS) of Textile } \\
\text { Effluent }\end{array}$ \\
\hline $\mathrm{pH}$ & $8.1 \pm 0.1$ & $7.1 \pm 0.2$ & 7 \\
COD (mg/L) & $1250.5 \pm 0.1$ & $120.4 \pm 0.1$ & 150 \\
BOD (mg/L) & $250.5 \pm 0.1$ & $70.3 \pm 0.1$ & 80 \\
Total suspended & $1150.5 \pm 0.2$ & $115.0 \pm 0.1$ & 150 \\
$\quad$ solids (mg/L) & & & 3500 \\
TDS (mg/L) & $3000.2 \pm 0.1$ & $2900.2 \pm 0.1$ & 7 \\
Color (PCU) & $75.0 \pm 0.1$ & $5.0 \pm 0.1$ & \\
\hline
\end{tabular}

\begin{tabular}{lllll}
\hline Coupled methods & BOD $(\%)$ & COD $(\%)$ & Color (\%) & References \\
\hline Fluidized bed Fenton-biological & 80 & 87.22 & - & Francis and Sosamony [21] \\
$\begin{array}{l}\text { Combination of physical-chemi- } \\
\quad \text { cal and biological }\end{array}$ & - & $>85$ & - & El Defrawy and Shaalan [17] \\
Hybrid textile wastewater & - & $82-94$ & 99 & Sandhya et al. [48] \\
AOP-biological & 90.37 & 71.92 & 90 & Present study \\
\hline
\end{tabular}

Table 7 Comparison with other works
The overall mechanism of enhanced photodecolorization of real textile industrial wastewater using catalysis $\mathrm{H}_{2} \mathrm{O}_{2}$

$\mathrm{TiO}_{2}+$ hv (energy $\left.>3.2 \mathrm{ev}\right) \rightarrow \mathrm{e}^{-}+\mathrm{h}^{+}$

$\mathrm{e}^{-}+\mathrm{O}_{2}$ (ads) $\rightarrow \mathrm{O}_{2}^{-}$(ads)

$\mathrm{h}^{+}+\mathrm{OH} \bullet_{(\mathrm{s})} \rightarrow \mathrm{OH}(\mathrm{s})$

$\mathrm{OH} \bullet+$ dye $\rightarrow$ degradation

Based on the coupling method, it is concluded that the treatment of wastewater from the real textile industry resulted in high degradation so that the color and COD removal efficiencies were $93.3 \%$ and $90.4 \%$, respectively. The procedure involves the first step with a photocatalytic experiment in which the pollutants are partially oxidized and converted into more biodegradable compounds; afterward, a second biological step is performed in which the contaminants are completely degraded or mineralized. Chemical pre-treatment is necessary to change the structure of the contaminants by converting them into non-toxic and readily biodegradable intermediates as shown in Fig. 4. These results are in the same efficiency range as studies with photo-Fenton (Garcia-Montano et al. 2006) and could enhance with an increase in time for biological treatment, as observed by Deveci et al. (2016).

The success of the combined processes with $\mathrm{TiO}_{2}$ is because they are complementary: The photocatalytic treatment removes color and the bioprocess removes carbon, improving the wastewater quality (Padovan and Azevedo 2015). Also, the photocatalytic pre-treatment may improve the biodegradation of textile wastewater, though change in the structures of the components, as observed by Ahmadi et al. (2015).

Besides, this study confirms that high decolorization efficiency and high removal of COD was gained without $\mathrm{pH}$ correction and less energy consumption compared to the implementation of AOPs alone. The results obtained in this study provide clear information for the design of pilot plants aiming at the treatment of real textile wastewater which can combine the advantages of conventional chemical and biological treatment methods overcoming the disadvantages of both the processes of real wastewater treatment plants.

\section{Conclusions}

In the present study, the sequential implementation of chemical and biological treatment processes to the treatment of a real textile effluent containing reactive azo dyes showed 
Fig. 4 General mechanism degradation of organic dye compounds using the photocatalytic and biological approach

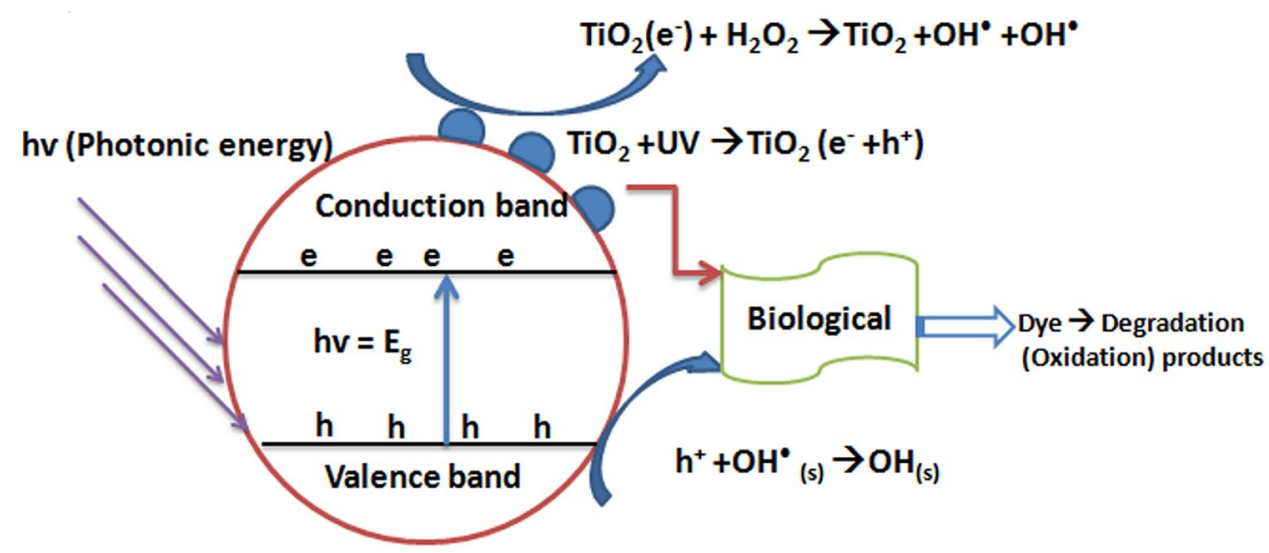

superior performance in color and COD removal in comparison to chemical or aerobic single-phase treatment systems alone.

This finding confirms the effectiveness of the sequential AOP and biological approach and showed a promising potential for the removal of color from real textile industrial wastewater compared to photocatalytic or biological treatment only. It is also worth noting that this technological solution is ready for application and can be easily implemented in the full-scale textile wastewater treatment plants due to the photocatalytic pre-treatment of the textile wastewater enhances the subsequent biodegradation through changing the structures of the components. Therefore, $\mathrm{TiO}_{2} /$ $\mathrm{H}_{2} \mathrm{O}_{2}$ /UV combined with microbial consortia and optimization of culture conditions process is a promising technology for textile wastewater treatment not only for color removal but also for dye mineralization purposes. Moreover, this technology can be used directly in dye baths before they are mixed with other textile wastewaters.

Acknowledgement The author would like to thank the chemistry department of Mekelle University for performing some of the tests.

Funding Open access funding provided by Università degli Studi di Brescia within the CRUI-CARE Agreement.

\section{Compliance with ethical standards}

Conflict of interest The authors declare that they have no conflict of interest.

Open Access This article is licensed under a Creative Commons Attribution 4.0 International License, which permits use, sharing, adaptation, distribution and reproduction in any medium or format, as long as you give appropriate credit to the original author(s) and the source, provide a link to the Creative Commons licence, and indicate if changes were made. The images or other third party material in this article are included in the article's Creative Commons licence, unless indicated otherwise in a credit line to the material. If material is not included in the article's Creative Commons licence and your intended use is not permitted by statutory regulation or exceeds the permitted use, you will need to obtain permission directly from the copyright holder. To view a copy of this licence, visit http://creativecommons.org/licenses/by/4.0/.

\section{References}

1. Ademoroti C (1996) Standard methods for water and effluents analysis, vol 3. Foludex Press Ltd, Ibadan, pp 29-118

2. An H, YiQian X, Walter Z (1996) Biological treatment of dye wastewaters using an anaerobic-oxic system. Chemosphere 33(12):2533-2542

3. Anuradha S, Karunya A, Ananth P, Swetha S, Nachiyar CV (2013) Kinetics of acid black 24 biodegradation. Indian J Biotechnol 8:2409-2413

4. Balamurugan B, Thirumarimurugan M, Kannadasan T (2011) Anaerobic degradation of textile dye bath effluent using Halomonas sp. Bioresour Technol 102(10):6365-6369

5. Bandala ER, Peláez MA, García-López AJ, Salgado MDJ, Moeller G (2008) Photocatalytic decolourisation of synthetic and real textile wastewater containing benzidine-based azo dyes. Chem Eng Process Process Intensif 47(2):169-176

6. Bansal P, Sud D (2011) Photodegradation of commercial dye, procion blue HERD from real textile wastewater using nanocatalysts. Desalination 267(2):244-249

7. Blanco J, Torrades F, De la Varga M, García-Montaño J (2012) Fenton and biological-fenton coupled processes for textile wastewater treatment and reuse. Desalination 286:394-399

8. Boye B, Dieng MM, Brillas E (2002) Degradation of herbicide 4-chlorophenoxyacetic acid by advanced electrochemical oxidation methods. Environ Sci Technol 36:3030-3035

9. Byrappa K, Subramani A, Ananda S, Rai KL, Dinesh R, Yoshimura M (2006) Photocatalytic degradation of rhodamine B dye using hydrothermally synthesized $\mathrm{ZnO}$. Bull Mater Sci 29:433-438

10. Cardoso JC, Bessegato GG, Zanoni MVB (2016) Efficiency comparison of ozonation, photolysis, photocatalysis and photoelectrocatalysis methods in real textile wastewater decolorization. Water Res 98:39-46

11. Chen CY, Cheng MC, Chen AH (2012) Photocatalytic decolorization of remazol black 5 and remazol brilliant orange $3 \mathrm{R}$ by mesoporous $\mathrm{TiO}_{2}$. J Environ Manag 102:125-133

12. Copley SD (2009) Evolution of efficient pathways for degradation of anthropogenic chemicals. Nat Chem Biol 5(8):559-566 
13. Daneshvar N, Salari D, Khataee A (2004) Photocatalytic degradation of azo dye acid red 14 in water on $\mathrm{ZnO}$ as an alternative catalyst to $\mathrm{TiO}_{2}$. J Photochem Photobiol A Chem 162:317-322

14. da Silva LS, Gonçalves MMM, Raddi de Araujo LR (2019) Combined photocatalytic and biological process for textile wastewater treatments. Water Environ Res 91(11):1490-1497

15. de Lima L, Pereira L, de Moura S, Magalhães F (2017) Degradation of organic contaminants in effluents synthetic and from the textile industry by Fenton, photocatalysis, and $\mathrm{H}_{2} \mathrm{O}_{2}$ photolysis. Environ Sci Pollut Res 24(7):6299-6306

16. Di Iaconi C (2012) Biological treatment and ozone oxidation: integration or coupling. Bioresour Technol 106:63-68

17. El Defrawy N, Shaalan H (2007) Integrated membrane solutions for green textile industries. Desalination 204(1-3):241-254

18. Eslami A, Moradi M, Ghanbari F, Mehdipour F (2013) Decolorization and COD removal from real textile wastewater by chemical and electrochemical fenton processes: a comparative study. J Environ Health Sci Eng 11(1):31

19. Farré MJ, Doménech X, Peral J (2006) Assessment of photo-Fenton and biological treatment coupling for Diuron and Linuron removal from water. Water Res 40:2533-2540

20. Forgacs E, Cserhati T, Oros G (2004) Removal of synthetic dyes from wastewaters: a review. Environ Int 30:953-971

21. Francis A, Sosamony K (2016) Treatment of pre-treated textile wastewater using moving bed biofilm reactor. Procedia Technol 24:248-255

22. Gadd GM (2010) Metals, minerals, and microbes: geomicrobiology and bioremediation. Microbiology 156:609-643

23. García-Montaño J, Domenech X, García-Hortal JA, Torrades F, Peral J (2008) The testing of several biological and chemical coupled treatments for Cibacron Red FN-R azo dye removal. J Hazard Mater 154:484-490

24. Ghanbari F, Moradi M (2015) A comparative study of electrocoagulation, electrochemical fenton, electro-fenton, and peroxicoagulation for decolorization of real textile wastewater: electrical energy consumption and biodegradability improvement. J Environ Chem Eng 3(1):499-506

25. Ghoreishi S, Haghighi R (2003) Chemical catalytic reaction and biological oxidation for treatment of non-biodegradable textile effluent. Chem Eng J 95:163-169

26. Gogate PR, Pandit AB (2004) A review of imperative technologies for wastewater treatment I: oxidation technologies at ambient conditions. Adv Environ Res 8:501-551

27. Grzechulska J, Morawski AW (2002) Photocatalytic decomposition of azo-dye acid black 1 in water over modified titanium dioxide. Appl Catal B Environ 36:45-51

28. Jonstrup M, Wärjerstam M, Murto M, Mattiasson B (2010) Immobilisation of $\mathrm{TiO}_{2}$ for combined photocatalytic-biological azo dye degradation. Water Sci Technol 62:525-531

29. Karunya A, Ananth P, Jabasingh SA, Nachiyar CV, Rose C (2010) A study on the construction of microbial consortia containing bacterial isolates capable of degrading AB113, ABK 24, MB17. Recent Adv Space Technol Serv Clim Change 2010:15-18

30. Karunya A, Nachiyar CV, Ananth P, Sunkar S, Jabasingh SA (2014) Development of microbial consortium CN-1 for the degradation of Mordant Black 17. J Environ Chem Eng 2:832-840

31. Khalik WF, Ong SA, Ho LN, Wong YS, Yusoff NA, Ridwan F (2015) Evaluation of the molecular structure of azo dye in photocatalytic mineralization under solar light irradiation. Desalination Water Treat 55(8):2229-2236

32. Knackmuss H-J (1996) Basic knowledge and perspectives of bioelimination of xenobiotic compounds. J Biotechnol 51:287-295

33. Konstantinou IK, Albanis TA (2004) $\mathrm{TiO}_{2}$-assisted photocatalytic degradation of azo dyes in aqueous solution: kinetic and mechanistic investigations: a review. Appl Catal B Environ 49:1-14
34. Koprivanac N, Kušić H, Vujević D, Peternel I, Locke BR (2005) Influence of iron on degradation of organic dyes in corona. J Hazard Mater 117:113-119

35. Lee H, Shoda M (2008) Removal of COD and color from livestock wastewater by the Fenton method. J Hazard Mater 153(3):1314-1319

36. Li M, Liao X, Zhang D, Du G, Chen J (2011) Yeast extract promotes cell growth and induces production of polyvinyl alcoholdegrading enzymes. Enzyme Res 2011:179819. https://doi. org/10.4061/2011/179819

37. Lucas MS, Dias AA, SampaioA Amaral C, Peres JA (2007) Degradation of a textile reactive Azo dye by a combined chemical-biological process: fenton's reagent-yeast. Water Res 41(5):1103-1109

38. Mantzavinos D, Psillakis E (2004) Enhancement of biodegradability of industrial wastewaters by chemical oxidation pre-treatment. J Chem Technol Biotechnol 79:431-454

39. Mantzavinos D, Sahibzada M, Livingston AG, Metcalfe IS, Hellgardt K (1999) Wastewater treatment: wet air oxidation as a precursor to biological treatment. Catal Today 53:93-106

40. Mbuligwe SE (2005) Comparative treatment of dye-rich wastewater in engineered wetland systems (EWSs) vegetated with different plants. Water Res 39(2):271-280

41. Mohabansi N, Patil V, Yenkie N (2011) A comparative study on photodegradation of methylene blue dye effluent by advanced oxidation process by using $\mathrm{TiO}_{2} / \mathrm{ZnO}$ photocatalyst. Rasayan J Chem 4:814-819

42. Nachiyar CV, Rajkumar GS (2003) Degradation of a tannery and textile dye, Navitan Fast Blue S5R by Pseudomonas aeruginosa. World J Microbiol Biotechnol 19:609-614

43. Neamtu M, Yediler A, Siminiceanu I, Macoveanu M, Kettrup A (2004) Decolorization of disperse red 354 azo dye in water by several oxidation processes - a comparative study. Dyes Pigments 60:61-68

44. Neppolian B, Choi H, Sakthivel S, Arabindoo B, Murugesan V (2002) Solar light induced and $\mathrm{TiO}_{2}$ assisted degradation of textile dye reactive blue 4 . Chemosphere 46:1173-1181

45. Oller I, Malato S, Sánchez-Pérez JA (2011) Combination of advanced oxidation processes and biological treatments for wastewaterdecontamination. A review. Sci Total Environ 409(20):4141-4166

46. Pereira LDO, de Moura SG, Coelho GC, Oliveira LC, de Almeida ET, Magalhães F (2019) Magnetic photocatalysts from industrial residues and $\mathrm{TiO}_{2}$ for the degradation of organic contaminants. J Environ Chem Eng 7(1):102826

47. Rodriguez-Lopez AD, Garcia-Garrido J, Perez-Ramiro C, GarciaCastello EM (2013) Discoloration on methylene blue solutions by direct and catalytic ozonation. J Mater Sci Chem Eng 1(5):33

48. Sandhya S, Sarayu K, Swaminathan K (2008) Determination of kinetic constants of the hybrid textile wastewater treatment system. Bioresour Technol 99(13):5793-5797

49. Sirirerkratana K, Kemacheevakul P, Chuangchote S (2019) Color removal from wastewater by photocatalytic process using titanium dioxide-coated glass, ceramic tile, and stainless steel sheets. J Clean Prod 215:123-130

50. Scott JP, Ollis DF (1995) Integration of chemical and biological oxidation processes for water treatment: review and recommendations. Environ Progress Sustain Energy 14:88-103

51. Shu H-Y, Chang M-C (2005) Decolorization effects of six azo dyes by $\mathrm{O}_{3}, \mathrm{UV} / \mathrm{O}_{3}$, and $\mathrm{UV} / \mathrm{H}_{2} \mathrm{O}_{2}$ processes. Dyes Pigments 65:25-31

52. Solcova O, Spacilova L, Maleterova Y, Morozova M, Ezechias M, Kresinova Z (2016) Photocatalytic water treatment on $\mathrm{TiO}_{2}$ thin layers. Desalination Water Treat 57(25):11631-11638 
53. Sumartono A, Andayani W (2011) Degradation of cibacron red dye using $\mathrm{ZnO}$ as a catalyst coated on the surface of the glass in the photocatalytic process. Atom Indonesia 37:119-125

54. Swaminathan M, Muruganandham M, Sillanpaa M (2013) Advanced oxidation processes for wastewater treatment. Int J Photoenergy 683682:1-3

55. Tomei MC, Angelucci DM, Daugulis AJ (2016) Sequential anaerobic-aerobic decolourization of a real textile wastewater in a twophase partitioning bioreactor. Sci Total Environ 573:585-593

56. Un UT, Aytac E (2013) Electrocoagulation in a packed bed reactor-complete treatment of color and cod from real textile wastewater. J Environ Manag 123:113-119

57. Wojnárovits L, Takács E, Szabó L (2017) Gamma-ray and electron beam-based AOPs. In: Stefan MI (ed), Advanced oxidation processes for water treatment: fundamentals and applications. IWA publishing, London

58. Wu DL, Wang W, Guo QW, Shen YH (2013) Combined FentonSBR process for bamboo industry wastewater treatment. Chem Eng J 214:278-284

59. Yatome C, Ogawa T, Koga D, Idaka E (1981) Biodegradability of azo and triphenylmethane dyes by Pseudomonas pseudomallei 13NA. Coloration Technol 97:166-169
60. Yogendra K, Mahadevan K, Naik S, Madhusudhana N (2011) Photocatalytic activity of synthetic $\mathrm{ZnO}$ composite against Coralene red F3BS dye in presence of solar light. Int J Environ Sci 1:839

61. Yuzer B, Aydin MI, Bulut FB, Palamutcu S, Emer U, Bekbolet M, Selçuk H (2015) Reuse of the treated textile wastewater and membrane brine in the wet textile processes: distorting effects on the cotton fabric. Desalination Water Treat 56(4):997-1009

62. Zouzelka R, Kusumawati Y, Remzova M, Rathousky J, Pauporté $T$ (2016) Photocatalytic activity of porous multiwalled carbon nanotube- $\mathrm{TiO}_{2}$ composite layers for pollutant degradation. J Hazard Mater 317:52-59

Publisher's Note Springer Nature remains neutral with regard to jurisdictional claims in published maps and institutional affiliations. 